\title{
48-72 Aylık çocuklar için LAP-3 gelişim değerlendirme ölçeği'nin geçerlik ve güvenirlik çalışması*
}

\author{
Validity and reliability study of LAP-3 development assessment scale for \\ 48-72 months children
}

\author{
Hilal İlknur Tunçeli ${ }^{1}$, Rengin Zembat ${ }^{2}$
}

\begin{abstract}
Makale Geçmişi
Geliş : 08 Ocak 2018

Düzeltme : 04 Şubat 2018

Kabul : 07 Şubat 2018

Çevrimiçi : 08 Şubat 2018
\end{abstract}

Makale Türü

Özgün Makale

\section{Article History}

Received : 08 January 2018

Revised : 04 February 2018

Accepted : 07 February 2018

Online : 08 February 2018

Article Type

Original Article
Öz: Erken çocukluk döneminde çocuğun gelişiminin hızı ve bu dönemdeki gelişim süreçleri ve öğrenme yaşantılarının ileriki yıllara katkısı göz önünde bulundurulduğunda çocuğun gelişiminin değerlendirilmesinin gerekliliği öne çıkmaktadır. Çocukların gelişiminin değerlendirilmesi için araştırmacılar, Ölçeği'nin Türkçe alan yazına kazandırılması amacıyla 48-72 aylık çocuklar için Türkçe uyarlaması yapılan "LAP-3 Gelişim Değerlendirme Ölçeği'nin geçerlik ve güvenirlik çalışması yapılmıştır. Araştırma nicel araştırma türünde tasarlanmıştır. Çalışma grubu amaçlı örnekleme yoluyla oluşturulmuş olup İstanbul ili Kadıköy, Çekmeköy, Sultanbeyli (Anadolu Yakası), Avcılar, Zeytinburnu, Bağcılar (Avrupa Yakası) ilçeleri seçilmiştir. Seçilen yedi okulda eğitim öğretime devam eden ve sınıf öğretmenleri tarafından normal gelişim gösterdiği belirtilen (okul kaydı sırasında herhangi bir tanı aldığı belirtilmemiş ve öğretmenin gelişimini normal olarak değerlendirdiği çocuklar) toplam 351 çocuk çalışma grubuna dahil edilmiştir. Araştırma kapsamında veriler; araştırmacı tarafından oluşturulan kişisel bilgi formu, LAP-3 Gelişim Değerlendirme Ölçeği (The Learning Accomplishment Profile-3rd Edition) kullanılarak toplanmıştır. Kriter geçerliği için Marmara Gelişim Ölçeği kullanılmıştır. Elde edilen veriler uygun bir istatistik paket programı ile analiz edilmiştir. Araştırmanın bütününde elde edilen sonuçlar göz önüne alındığında LAP-3 Gelişim Değerlendirme Ölçeği'nin Türk çocukları için geçerli ve güvenilir bir ölçme aracı olduğu görülmüştür.

Anahtar Kelimeler: Gelişim, değerlendirme, LAP-3 Gelişim Değerlendirme Ölçeği.

\begin{abstract}
Considering the speed of development of the child in the early childhood period and the contribution of developmental processes and learning experiences to the future years, the necessity of assessing child development comes to the fore. The objective is to perform validity and reliability study of "LAP-3 Development Assessment Scale" adopted to Turkish for children aged between 4872 months. The study is designed as a quantitative study. Study group was formed by sampling and Kadıköy, Çekmeköy, Sultanbeyli (Anatolian Side), Avcılar, Zeytinburnu, Bağcılar (European Side) districts of İstanbul province were selected. A total of 351 children who were studying in the seven selected schools and whose teachers stated that they had normal development were included in the study. Data were collected using the personal information form and LAP-3 Development Assessment Scale (LAP-3). For the validity of the criteria, Marmara Development Scale was used. Collected data were analyzed using a relevant statistics package program. Considering the results obtained from the study as a whole, it was found that LAP-3 Development Assessment Scale is a valid and reliable measurement tool for Turkish children.
\end{abstract}

Keywords: Development, assessment, LAP-3 Development Assessment Scale.

* Bu çalışma ilk yazarın Marmara Üniversitesi Eğitim Bilimleri Enstitüsü’nde tamamladığı doktora tezinden türetilmiştir. 


\section{SUMMARY}

\section{Introduction}

Considering the speed of development of the child in the early childhood period and the contribution of developmental processes and learning experiences to the future years, the necessity of assessing child development comes to the fore. The study, which aims to bring "LAP-3 Development Assessment Scale" in Turkish in order for it to be used as an efficient tool for the assessment of child development by the investigators, teachers and families. The objective is to perform validity and reliability study of "LAP-3 Development Assessment Scale" adopted to Turkish for children aged between 48-72 months.

\section{Method}

The study is designed as a quantitative study. Study group was formed by sampling and Kadıköy, Çekmeköy, Sultanbeyli (Anatolian Side), Avcılar, Zeytinburnu, Bağcılar (European Side) districts of İstanbul province were selected. In the selected districts, schools affiliated with District National Education Directorates were listed and in the selection criteria for the schools was the presence of appropriate physical conditions (scaling ladder, bar, empty space suitable for biking, etc.) for the assessment of the items particularly in the gross motor development and fine motor development subdimensions of LAP-3 Development Assessment Scale. A total of 351 children who were studying in the seven selected schools and whose teachers stated that they had normal development (children who had normal development at the time of enrollment and whose teachers considered their development as normal) were included in the study.

Within the scope of the study; data were collected using the personal information form designated by the researcher and LAP-3 Development Assessment Scale (LAP-3). For the validity of the criteria, Marmara Development Scale was used. Collected data were analyzed using a relevant statistics package program. Within the scope of validity and reliability study of the assessment tool, structure and criteria validity, mean, standard deviation and standard error points in the measurement, inherent consistency (Kuder Richardson 20), test-re-test and inter-rater correlation coefficient were calculated.

\section{Results}

Based on the results obtained from performing the appropriate analyses, it was found that the Zero order correlation results, which were obtained from the age variable-based Zero order and partial correlation analysis of the scores children got from LAP-3 Development Assessment Scale sub-tests to analyze structure validity, varied between 0.69 and 0.89 . It was found that the result of the partial correlation, which was calculated via the sub-test total scores by keeping age under control, were lower than the zero-order correlation results (.22-.64), indicating that the sub-tests of the LAP-3 Development Assessment Scale were correlated and each of them measure different aspects of development. 
According to the results of the analysis of the criterion validity of the measurement tool; The relationship between the LAP-3 Developmental Assessment Scale and the Marmara Developmental Scale was examined and it was determined that there are positive correlations on intermediate and high levels. Inherent consistency coefficient of the measurement tool, Kuder Richardson 20 value, varied between .91 and .98 for the whole of the LAP-3 Development Assessment Scale. For LAP-3 Development Assessment Scale, inter-rater consistency was analyzed and it was found that in all tests, inter-rater consistency had a correlation value of .82 and higher. The result of test-re-test analysis showed that the consistency of the measurement tool between the first and last application in all tests had a correlation value of .93 and higher.

\section{Conclusion}

Considering the results obtained from the study as a whole, it was found that LAP-3 Development Assessment Scale is a valid and reliable measurement tool for Turkish children. For the validity studies on LAP-3 Developmental Assessment Scale, content validity was examined by the views of area experts; construct validity was examined by the zero order and partial correlations analysis; criterion validity was examined by the correlations between Marmara Development Scale and LAP-3. Also for the reliability studies on LAP-3 Developmental Assessment Scale was examined by correlations between chronological age and LAP-3 raw scores; internal consistency analysis (KR-20), Standard errors of measurement, test-retest and interrater reliability analysis. The conclusions of all validity and reliability analysis is coherent with the orijinal validity and reliability analysis of LAP-3 made by Hardin ve Peisner Feinberg (2004). Studies using LAP-3 Development Assessment Scale to evaluate children in all developmental aspects will enable systematic and appropriate assessment of children; and due to its structure complying with the achievements and indicators in the pre-school education program, the support children require based on the results of the assessment will be easily provided via the education programs designated by the teachers. 


\section{GİRISs}

Gelişim bilimi üzerine çalışan bilim insanları gelişimin ne olduğu ve nasıl bir yol izlediği konusunda yıllar boyunca farklı görüşler ortaya koymuşlardır. Son yıllarda da gelişimle ilgili konular ele alınırken disiplinler arası yaklaşım sergilenmesinin bir ihtiyaç olduğu benimsenmeye başlanmıştır. Bu durum gelişimin tanımında da farklılaşmalara yol açmıştır. En genel anlamıyla gelişim kavramı, organizmanın kalıtım ve çevreyle etkileşimi sonucunda, uyumunu arttıran sistemli, düzenli, ardışık ve sürekli değişimler bütünü olarak tanımlanabilir (Overton, 2010; Salkind, 2002; Santrock, 2013; Senemoğlu, 2012).

Gelişim, biyolojik (fiziksel varlığımızdaki değişimler), sosyal (sosyal ilişkilerimizdeki değişimler), duygusal (duygusal anlayışımız ve deneyimlerimizdeki değişimler), bilişsel (düşünme süreçlerimizdeki değişimler) alanlar gibi farklı alanlarda gerçekleşir (Keenan, Evans, Crowley, 2016, s.5).

Gelişimden bahsederken gelişimle ilgili temel kavramları da bilmek gereklidir. Bunlar; büyüme, olgunlaşma, öğrenme ve hazırbulunuşluk kavramlarıdır. Büyüme, vücudun fiziksel olarak değişimini kapsamakta, boy, kilo ve hacim olarak artışını ifade etmektedir. Büyüme, vücudun değişik kısımlarında farklı hızlarda gerçekleşebilir. (Senemoğlu, 2012, s.3.). Olgunlaşma, genlerimiz tarafından kontrol edilen ve belirlenen ve öğrenme yaşantılarından bağımsız gerçekleşen bir büyüme sürecidir (Keenan, Evans ve Crowley, 2016; Senemoğlu, 2012). Olgunlaşma kavramı çoğu zaman fiziksel gelişimle ilişkilendirilmesine rağmen tüm gelişim alanlarında gerçekleşen büyüme, gelişme ve değişimde önemli bir rol oynamaktadır (Hills, Bryne, 2010; Malina, Bouchard ve Bar-or, 2004; Manna, 2014; Wise, 2014). Bununla birlikte öğrenme, bireyin her türlü çevresel faktörün etkisiyle oluşturduğu deneyimler ve bunun sonucunda bireyde meydana gelen kalıcı izli değişikliklerdir (Senemoğlu, 2012; Wise, 2014). Hazırbulunuşluk ise, belli bir öğrenme faaliyetini gerçekleştirebilmek için bilişsel, sosyal, fiziksel ve duyuşsal olarak hazır olma hali olarak tanımlanabilir (Senemoğlu, 2012; Bacanl1;2016).

Gelişimle ilgili olarak ele alınması gereken bir diğer önemli kavram da gelişimin kritik dönemleridir. Bireyin belli gelişim dönemlerinde ve yaşlarda belli türdeki öğrenme süreçlerine karşı yüksek duyarlılık gösterme eğilimi olarak tanımlanan kritik dönemlerden birisi de erken çocukluk dönemidir (Senemoğlu, 2012, s. 5). Erken çocukluk dönemi çocuğun ileriki yıllarında öğrenme yaşantıları, refahı ve üretkenliği için temel oluşturmaktadır. Yaşamın ilk sekiz yılı boyunca çocuklar hayatlarının diğer dönemlerinden daha hızlı bir şekilde büyür ve gelişirler. Birçok gelişim alanında ilk sekiz yıl içinde tüm yaşam boyunca kat edilecek yolun yarısının 
alındığı belirtilmiştir. Bu dönemde yapılacak erken müdahaleler bireylerin bilişsel kapasiteleri, kişilikleri ve sosyal davranışları üzerinde kalıcı bir etki gösterecektir (Bergen ve Robertson, 2013; Bredekamp, 2015; Oktay, 2004; UNICEF, 2003).

Erken çocukluk döneminde çocuğun gelişiminin hızı ve bu dönemdeki gelişim süreçleri ve öğrenme yaşantılarının ileriki yıllara katkısı göz önünde bulundurulduğunda çocuğun gelişiminin değerlendirilmesinin gerekliliği öne çıkmaktadır. Değerlendirme; çocukların öğrenme ve gelişimine ilişkin sürekli olarak veri toplama ve arkasından öğretime ilişkin doğru kararlar verme amaciyla elde edilen bilgileri düzenleyip yorumlama süreci olarak tanımlanabilir (Bredekamp 2015, s. 342).

Çocukları değerlendirirken bireysel farklılıklarını göz önüne almak gereklidir. Çocukların gelişimsel süreçleri birbirine benzer olsa da aynı değildir. Ayrıca her çocuğun ailesi, kültürel ve yaşantısal geçmişi birbirinden farklıdır. Bu nedenle erken çocukluk döneminde "tek tip" değerlendirme bu dönem çocuğunun ihtiyaçlarını karşılamayacaktır (Shepard, Kagan ve Wurtz, 1998, s 32-33).

Erken çocukluk döneminde değerlendirme, tek tip olmamasının yanı sıra büyük çocukların değerlendirilmesinden de birçok yönüyle farklılaşmaktadır. En büyük fark, erken çocukluk dönemi çocuklarının öğrenme biçimleridir. $\mathrm{Bu}$ dönemde çocuklar bilgiyi, kağıt kalem kullanarak ya da soyut düşünme yoluyla değil; deneyimleri, etkileşimleri, yaptıkları ve konsantrasyonları yoluyla yapılandırırlar (Bredekamp ve Rosegrant, 1995, s.10).

Çocuklar öğrenmek için mutlaka nesnelere dokunmalı, manipüle etmeli, görseller oluşturmalı, anlattıklarımızı-hikayelerimizi dinleyerek canlandırmalı, model almalı, konuşmalı ve şarkı söylemeli, hareket etmeli ve oyun oynamalıdır. Sonuç olarak çocukların ne bildiğini ve yapabildiğini ifade edebilmesi için kağıt ve kalem yoluyla yapılan geleneksel değerlendirmelerden başka yöntemler kullanılmalıdır. Erken çocukluk dönemi çocuğunu değerlendirmek, gelişimin hılı olması, kendine özgü bir yol takip etmesi ve çevreden fazlasıyla etkilenmesi nedeniyle güçtür (Shepard, Kagan ve Wurtz, 1998, s.4-5).

Çocukların gelişimleri değerlendirilirken sıklıkla kullanılan yöntemlerden biri standart testlerdir. Uygulama ve puanlama kriterleri önceden belirlenmiş ve aynı koşullar altında, aynı işi yapan tüm çocukların aynı şartlar ile değerlendirildiği standart testlerin geçerlik ve güvenirliğe sahip olmaları gerekir (AERA, APA ve NCME, 2014).

Standart testler puanlama türlerine göre "ölçüt bağımlı testler" ve "norm bağımlı testler" olmak üzere ikiye ayrılmaktadır. Ölçüt bağımlı testler, bireylerin bilgi ve beceriyi ne düzeyde ve ne 
kadar iyi öğrendiğini ölçmek için tasarlanmıştır. Bireyin başarılı olabilmesi için uzmanlar tarafından önceden belirlenmiş belli sayıdaki soruyu doğru cevaplaması gerekmektedir. Norm bağımlı testler ise ölçüt bağımlı testlerin aksine bir kişinin testten aldığı puanı teste giren diğer kişilerin puanları ile karşılaştırmak için tasarlanmıştır. Bu testlerden elde edilen puanlar, teste girenlerin yarısı ortalamanın üzerinde, yarısı altında kalacak şekilde yüzdelik dilimler halinde sunulur (Fairtest, 2007).

Erken çocukluk döneminde yapılacak değerlendirmenin; eğitim ve öğretimin desteklenmesi, özel eğitime veya gelişimsel desteğe gereksinimi olan çocukların belirlenmesi, eğitim programının değerlendirilmesi ve sorumluluğun değerlendirilmesi olmak üzere dört temel amac1 bulunur (Shepard, Kagan ve Wertz, 1998, s. 7.).

Bu dört temel amaçtan biri olan özel eğitime veya gelişimsel desteğe gereksinimi olan çocukları belirleme sürecinde tanılama ya da tarama testleri kullanılır. Tanılayıcı testler ile tarama testleri temelde birbirlerine benzemekle birlikte tanılayıcı testlerin uygulamaları bu konuda uzmanlaşmış kişiler tarafından yapılmalı ve doğru tanılama yapılabilmesi için uygun ölçme araçları kullanılmalıdır. Tarama testleri tanılayıcı testlerden farklı olarak herhangi bir tanı koyma amacı gütmeden mevcut durumu değerlendirme ve varsa riskleri tespit etmeye yardımcı olmaktadır (Bredekamp, 2015; McAfee ve Leong, 2012).

Çocukların gelişimlerini değerlendirmek üzere kullanılan tüm ölçme araçlarının uygulama süreçlerinde ve değerlendirmelerinde etik kurallar gözetilmeli, objektif yorumlamalar yapılmalıdır. Uygulanan tek bir değerlendirme tekniği ile çocuklara çocuklar kesin tanılar konulmamalıdır. Erken çocukluk döneminin, insan hayatında gelişimsel anlamda kritik bir dönem olması sebebiyle değerlendirmeler yoluyla eksiklerin ve varsa problemlerin erkenden belirlenmesi ve bunlara yönelik gerekli önlemlerin alınarak çocuğun gelişiminin desteklenmesi gerekmektedir (Bredekamp, 2015; Fairtest, 2007; Horton ve Bowman, 2002).

Yurt dışında ve yurt içinde çocukların gelişsimini değerlendirmek için uygulama süreci, değerlendirme kriterleri ve etki alanları birbirinden farklı ölçme araçları (Denver II, Gesell Developmental Schedules Test, Ages and Stages Questionnaire, Learning Accomplishment Profile-3, Gazi Erken Çocukluk Değerlendirme Aracı, Ankara Gelişim Tarama Envanteri, Marmara Gelişim Ölçeği v.b.) bulunur. Bununla birlikte dünyada çocukların gelişimini değerlendirme ve taramaya yönelik çeşitli uygulama süreci, puanlama ve etki alanına sahip çok sayıda ölçme aracı bulunmasına karşılık ülkemizde uygulanan ölçme araçlarının sınırlı sayıda olduğu görülmektedir. 
$\mathrm{Bu}$ durumdan yola çıkılarak okul öncesi dönem çocuklarının genel gelişimini değerlendirmek için Anna R. Sanford ve arkadaşları tarafından 1969 yılında geliştirilen, 1981 ve 2003 yıllarında revizyonu yapılan “ LAP-3 Gelişim Değerlendirme Ölçeği (The Learning Accomplishment Profile- 3rd Edition)'nin 48-72 aylık çocuklar için geçerlik ve güvenirlik çalışmaları yapılarak Türkçe 'ye uyarlanması araştırmanın problemini oluşturmaktadır. Bu araştırmanın genel amacı, 48-72 aylık çocukların genel gelişimlerini değerlendirmeye yönelik "LAP-3 Gelişim Değerlendirme Ölçeği "nin geçerlik ve güvenirlik çalışmalarının yapılmasıdır. Araştırmada ele alınan problemlere dayalı olarak, iki temel amaç bulunmaktadır:

1. "LAP-3 Gelişim Değerlendirme Ölçeği” güvenilir bir ölçme aracı mıdır?

2. "LAP-3 Gelişim Değerlendirme Ölçeği” geçerli bir ölçme aracı mıdır?

\section{YÖNTEM}

$\mathrm{Bu}$ bölümde araştırmanın modeli, verilerin elde edildiği çalışma grubu, veri toplamada kullanılan araçlar, veri toplama işlemi ve verilerin analizinde kullanılan istatistiki teknikler yer almaktadır.

\section{Araştırmanın Modeli}

Araştırma nicel araştırma türünde tasarlanmıştır. Araştırmada, tarama modellerinden ilişkisel tarama modeli kullanılmıştır. Tarama modelleri geçmişte ya da halen var olan bir durumu var olduğu şekliyle betimlemeyi amaçlayan araştırma yaklaşımlarıdır. İlişkisel tarama modelleri, iki veya daha çok değişken arasında birlikte değişim varlığını ve/veya derecesini belirlemeyi amaçlayan araştırma modelleridir (Karasar, 2016, s. 77). Araştırma temel olarak iki bölümden oluşmaktadır. Araştırmanın ilk bölümünde “LAP-3 Gelişim Değerlendirme Ölçeği”nin Türkçe 'ye uyarlanması aşamaları ile geçerlik ve güvenirlik analizleri yapılmıştır. İkinci bölümünde ise 48-72 aylık çocukların gelişimleri çeşitli değişkenler bakımından incelenmiştir.

\section{Çalışma Grubu}

Araştırmanın çalışma grubu seçkisiz olmayan örnekleme yöntemlerinden amaçlı örnekleme yoluyla oluşturulmuştur. Amaçlı örnekleme, araştırma sürecindeki belirlenen durumların derinlemesine çalışılmasına olanak verir. Bu tür örneklemede araştırmacı kimlerin/nelerin seçileceği konusunda kendi yargısını kullanır ve araştırmanın amacına en uygun olanları örnekleme alır (Balcı, 2015; Johnson ve Christensen, 2014). Bu araştırmada amaçlı örnekleme yöntemlerinden ölçüt örnekleme yöntemi kullanılmıştır. Ölçüt örnekleme yöntemi ise önceden belirlenmiş bir dizi ölçütü karşılayan durumların çalışılması olarak tanımlanmaktadır. Sözü 
edilen ölçüt yada ölçütler araştırmacılar tarafından oluşturulabilir yada daha önceden hazırlanmış bir ölçüt listesi kullanılabilir (Şimşek ve Yıldırım, 2013, s. 112).

$\mathrm{Bu}$ araştırmada çalışma grubunu belirlemek amacıyla kullanılan ölçütler araştırmacı ve alan uzmanları eşliğinde belirlenmiştir. Öncelikle İstanbul İli Anadolu yakasındaki 14 ve Avrupa yakasında 25 olmak üzere toplam 39 ilçe arasından kolay ulaşılabilirlik ilkesi göz önüne alınarak; Kadıköy, Çekmeköy, Sultanbeyli (Anadolu Yakası), Avcılar, Zeytinburnu, Bağcılar (Avrupa Yakası) ilçeleri seçilmiştir. Seçilen ilçelerde İlçe Milli Eğitim Müdürlükleri’ne bağlı okullar listelenmiş ve uygulamaya dahil edilecek okulların LAP-3 Gelişim Değerlendirme Ölçeği'nde özellikle kaba motor ve ince motor gelişim alt boyutlarında yer alan maddelerin değerlendirilebilmesi için uygun fiziksel koşullara (Tırmanma merdiveni, bar, bisiklet kullanımına uygun boş alan v.b.) sahip olması ölçütü aranmıştır. Bu ölçütleri sağlayan okullardan çalışmaya katılmaya gönüllü olan okullar belirlenmiştir. Belirlenen okullarda mümkün olduğunca sınıf listelerinin tamamındaki çocuklara ulaşılmaya çalışılmıştır. Seçilen yedi okulda eğitim öğretime devam eden ve sınıf öğretmenleri tarafından normal gelişim gösterdiği belirtilen (okul kaydı sırasında herhangi bir tanı aldığı belirtilmemiş ve öğretmenin gelişimini normal olarak değerlendirdiği çocuklar) toplam 351 çocuk çalışma grubuna dahil edilmiştir (Tablo 1).

Tablo 1. Çalışma grubuna ilişkin demografik özellikler

\begin{tabular}{llll}
\hline Demografik Bilgiler & & $\boldsymbol{f}$ & $\boldsymbol{\%}$ \\
\hline \multirow{2}{*}{ Cinsiyet } & Kız & 144 & 41,0 \\
& Erkek & 207 & 59,0 \\
\hline \multirow{2}{*}{ Kronolojik Yaş } & $48-53$ ay & 47 & 13,4 \\
& $54-59$ ay & 49 & 14,0 \\
& $60-65$ ay & 129 & 36,8 \\
Anne Yaşı & $66-72$ ay & 126 & 35,9 \\
\hline \multirow{3}{*}{ Baba Yaşı } & $18-33$ & 168 & 47,9 \\
& $34-40$ & 159 & 45,3 \\
& 41 ve üstü & 24 & 6,8 \\
\hline \multirow{2}{*}{ Anne öğrenim durumu } & $18-33$ & 80 & 22,8 \\
& $34-40$ & 213 & 60,7 \\
& 41 ve üstü & 58 & 16,5 \\
\hline \multirow{2}{*}{ Anne Çalışma Durumu } & Okuryazar değil & 6 & 1,7 \\
& İlkokul & 49 & 14,0 \\
& Ortaokul & 46 & 13,1 \\
& Lise & 145 & 41,3 \\
& Üniversite & 82 & 23,4 \\
& Lisansüstü & 23 & 6,6 \\
\hline
\end{tabular}




\begin{tabular}{llll}
\hline \multirow{2}{*}{ Baba Çalışma Durumu } & Çalışıyor & 325 & 92,6 \\
& Çalışmıyor & 26 & 7,4 \\
\hline \multirow{2}{*}{ Kardeşi Olma Durumu } & Kardeşi Yok & 117 & 33,3 \\
& Kardeşi Var & 234 & 66,7 \\
\hline \multirow{2}{*}{ Daha önce okul öncesi eğitim alma durumu } & Evet & 168 & 47,9 \\
& Hayır & 183 & 52,1 \\
\hline \multirow{2}{*}{ Okul öncesi eğitim alma süresi } & 1 yıl & 86 & 24,5 \\
& 2 yil & 70 & 19,9 \\
\hline Toplam & 3 yıl & 12 & 3,4 \\
\hline
\end{tabular}

Veri Toplama Araçları

Araştırma kapsamında veriler; araştırmacı tarafından oluşturulan Kişisel Bilgi Formu, LAP-3 Gelişim Değerlendirme Ölçeği ve Marmara Gelişim Ölçeği kullanılarak toplanmıştır. Marmara Gelişim Ölçeği yalnızca LAP-3 Gelişim Değerlendirme Ölçeği’nin kriter geçerliği için kullanılmıştır.

\subsubsection{Kişisel Bilgi Formu}

Araştırmaya katılan 48-72 aylık çocukların ve ailelerinin demografik özelliklerini belirlemek amacıyla araştırmacı tarafından "Kişisel Bilgi Formu” hazırlanmıştır. İlgili form çocukların cinsiyet, kronolojik yaş, anne-baba yaş, anne-baba öğrenim ve anne-baba çalışma durumu, kardeşi olma durumu, daha önce okul öncesi eğitim alma durumu ve süresinin belirlenmesinde kullanılmak üzere hazırlanmıştır.

\subsubsection{LAP-3 Gelişim Değerlendirme Ölçeği ve Uyarlama Süreci (The Learning Accomplishment Profile 3rd Edition)}

LAP-3 Gelişim Değerlendirme Ölçeği 36-72 aylık çocukların gelişimlerini değerlendirmeyi sağlayan ölçüt bağımlı bir ölçektir. Normal gelişim gösteren ve özel gereksinimli çocuklar için kullanılabilen LAP-3 Gelişim Değerlendirme Ölçeği öğretmenler, uzmanlar ve ailelere çocukları yedi gelişim alanı üzerinden bireysel olarak değerlendirme imkanı sağlar. Ölçek The Chapel Hill Sosyal Yardım Vakfı (Kuzey Karolina) ve Anne R. Sanford (1969) işbirliği ile çocukların gelişimlerini değerlendirmek ve ihtiyaçlarına yönelik eğitim imkanları sunmak amacıyla geliştirilmiştir. Anne R. Sanford ve Janet G. Zelman tarafından (1981) ilk revizyon çalışması yapılarak LAP-R olarak güncellenmiştir. 2001-2003 yılları arasında ölçek tekrar revize edilmiş günümüz eğitim şartlarına göre organize edilerek geçerlik güvenirlik çalışmaları tekrarlanmıştır (Hardin ve Peisner Feinberg, 2004, s.1-2).

LAP-3 Gelişim Değerlendirme Ölçeği her çocuğun bireysel olarak değerlendirilmesi, yedi gelişim alanı açısından ayrıntılı olarak ele alınması, 36-72 aylık normal gelişim gösteren çocukların yanı sıra özel gereksinimli çocuklara da uygulanabilir olması açısından öne çıkar. 
Ölçekteki maddeler daha önce alan uzmanlarının geliştirdiği ölçekler incelenerek hazırlanmıştır. Ölçek toplamda 383 maddeden oluşur. Maddeler yedi gelişim alanı için kronolojik aralıklar göz önüne alınarak hiyerarşik olarak düzenlenmiştir.

Ölçeğin kullanımı için yasal sahibinden e-posta yoluyla uygulama süreci için kullanım izni alınmıştır. Kullanım izninde belirtilen süreye kadar tüm uygulamalar tamamlanmıştır. Araştırmanın çalışma grubunun 48-72 aylık çocuklardan seçilmesi ve ölçeğin uygulama sürecinde çocuğun kronolojik yaşından başlanarak ardarda sekiz doğru cevap verdiği nokta bazal puan olarak belirlenmesi nedeniyle ölçeğin uyarlama sürecine 42-72 aya yönelik maddeler dahil edilmiştir. Bazal puan belirlenirken 42 aya ait maddelerden daha geriye gidilmesi gereken çocuklar çalışmaya dahil edilmemiştir.

42-72 aylık çocuklara uygulanmak üzere uyarlanan ölçekte, orijinalinde yer alan yedi gelişim alanında değişiklik yapılmazken, madde sayılarında azalma meydana gelmiştir. Uyarlaması yapılmak üzere hazırlanan formda yer alan madde sayıları: Kaba Motor: 36 madde, İnce motor: 23 madde, Okuma Yazmaya Hazırlık: 26 madde, Bilişsel: 68 madde, Dil: 48 madde, Özbakım: 29 madde, Kişisel/Sosyal: 26 madde olmak üzere toplamda 256 olarak düzenlenmiştir.

Ölçeğin geçerlik ve güvenirlik çalışmaları boyunca yapılan tüm analizler ölçeğin geliştirilmesi sırasında yapılan analizler göz önüne alınarak yapılmıştır. Uyarlama çalışmaları için öncelikle dil geçerliliği çalışmaları kapsamında ölçeğin İngilizce 'den Türkçe 'ye çevirisi yapılmış ve Türkçe dil uzmanları tarafından incelenmiştir. Türkçe dil uzmanlarının önerileri doğrultusunda yapılan düzeltmelerin ardından ölçeğin Türkçe formu tekrar İngilizce 'ye çevrilerek dil alan uzmanları tarafından her iki İngilizce formun kontrolleri yapılmıştır.

Çevirinin ardından kapsam geçerliği için okul öncesi eğitim konusunda farklı üniversitelerde çalışmakta olan beşi Profesör ikisi Doçent olmak üzere 7 okul öncesi eğitim alan uzmanına ölçeğin orijinali ve Türkçe çeviri hali gönderilmiş ve uygulanacak çalışma grubuna uygunluğu açısından alan uzmanlarından görüş istenmiştir. Alan uzmanlarından gelen görüşler doğrultusunda Dil Gelişimi alt testinde yer alan maddelere yönelik uygulama kitabında yer verilen ancak Türkçe alfabede yer almayan W, Q, X gibi harfler çıkarılarak Türkçe alfabede yer alan harfler eklenmiştir. Bilişsel gelişim alt testinde Madde $87^{\prime}$ de yer alan bozuk paralar Türk parasına uygun olarak 10, 25, 50 kuruş ve 1TL olarak revize edilmiştir. Dil Gelişimi alt testinde yer alan Madde 63, 66, 68'de yer alan İngilizce kelimeler Türkçe karşılıkları ya da yazılış yapısı olarak benzer kelimelerle yer değiştirilmiştir. Okumaya yazmaya hazırlık alt testi Madde 24 "te yer alan "CAT” sözcüğü çocuğun bir resim olarak algılayıp aynısını kağıda kopya etmesi yönergesini içerdiğinden değiştirilmemiştir. Kaba motor gelişimde koşma ile ilgili 
maddelerde okulların fiziksel ortamlarının uygun alana sahip olmadığı durumlarda aynı çocuğun aynı mesafeyi koşmasını sağlayacak şekilde kısa ama tekrarlı turlar yapmasına imkan verecek parkurlar oluşturularak değerlendirme yapılmıştır. Ülkemiz okul öncesi eğitim programında okuma yazmayı öğretme amacı olmamasına rağmen bazı özel kurumlarda buna yönelik eğitimler verilmesi sebebiyle ölçeğin özellikle okumaya yönelik maddeleri çıkarılmamıştır. Ancak okuma yazmaya yönelik eğitim vermeyen kurumlarda puanlamaya etkisi olmayacağından bu maddeler dışarıda bırakılarak değerlendirme yapılabilir. Özbakım ve Kişisel/Sosyal gelişim alt testlerinde yer alan sınıf içinde gözlenmesi mümkün olmayan maddeler için ölçeğin orijinalinde de yer aldığı üzere ailelerden bilgi alınması yoluna gidilmiştir. Alan uzmanlarından gelen bu görüşler doğrultusunda ölçek tekrar gözden geçirilerek düzenlenmiş ve Türkçe Formu'na son hal verilmiştir. Gelen uzman görüşleri doğrultusunda son hal verilen Türkçe formunun 30 çocukla pilot uygulaması yapılmıştır ancak bu çocuklarla yapılan uygulamalar veri setine dahil edilmemiştir. Pilot uygulamalarda yönergelerin açık ve anlaşılır olması, ölçeğin çocuklara sunuluş şekli ve uygulama esnasında yaşanabilecek olası sorunlar/aksaklıklar değerlendirilmiş gerekli önlemler alınmıştır.

Ölçekteki her bir madde için uygun materyaller hazırlanmıştır. Bu materyaller eşliğinde çocuklara yönergeler verilerek uygulama süreci gerçekleştirilir. Her alt testteki maddeler aylara göre gruplandırılmıştır. Uygulama yapılan yaş grubuna uygun maddelerden başlanarak ölçek uygulanır. Her maddenin sol tarafında hangi yaşa uygulanması gerektiği sağ tarafında ise ölçeğin setinde bulunan hangi materyallerin nasıl kullanılacağına dair bilgiler yer almaktadır. Maddelerin cevapları artı (+) ve eksi (-) olarak puanlanır. Ölçeğin puanlanması sürecinde iki kriter gözetilecektir, bazal ve tavan kriterleri. Bazal kriter belirlenirken çocuğun kronolojik yaşına uygun maddeden başlanarak ardı ardına 8 doğru cevap verdiği nokta çocuğun bazal puanını oluşturur ve ardışık olarak maddeler değerlendirilmeye devam edilir. Çocuğun her bir alt test için 5 soru içinde 3 yanlış cevap verdiği noktada o alt test için uygulama sonlandırılır ve bu nokta çocuğun tavan puanını oluşturur (Hardin ve Peisner Feinberg, 2004, s. 19-22).

Eğer çocuk cevap vermeyi reddediyorsa o madde yanlış olarak değerlendirilir. Eğer çocuk uygulama boyunca herhangi bir maddeye verdiği cevabı değiştirirse son verdiği cevaba göre puanlaması yapılır. Ayrıca her maddeye ilişkin bir aktivite kartı bulunur. Ölçek her çocukla ortalama 1.5 saat sürer. Ama çocuğun ilgi ve dikkat süresine göre ölçek farklı zamanlarda bölüm bölüm uygulanabilir. Ölçek sınıftan bağımsız sessiz bir köşede masa başında araştırmacı tarafindan uygulanmalıdır (Hardin ve Peisner Feinberg, 2004, s. 23-24). 
Ölçeğin geçerlik güvenirlik çalışmalarında test-tekrar-test, araştırmacılar arsası güvenirlik ve kriter geçerliliği çalışmalarının yanı sıra her bir gelişim alanına ait iç tutarlılık katsayıları, standart sapma hataları hesaplanarak yapılmıştır. Ölçeğin geçerlik güvenirlik çalışmaları sonucunda hem normal gelişim gösteren çocuklar hem de özel gereksinimli çocuklar için uygulanabilir olduğu belirtilmiştir (Hardin ve Peisner Feinberg, 2004, s.27).

\subsubsection{Marmara Gelişim Ölçeği}

Oktay ve Aydın (2002) tarafından 3-6 yaş çocuklarının gelişim düzeylerini belirlemek amacıyla geliştirilmiştir. Bu ölçek çocuklarının gelişimlerini 6 farklı gelişim boyutunda ele alır ve her boyuttaki gelişimi ayrı ayrı değerlendirme olanağı sağlar. Bu boyutlar bedensel gelişim (73 madde), özbakım becerileri (40 madde), duygusal gelişim (19 madde), sosyal gelişim (44

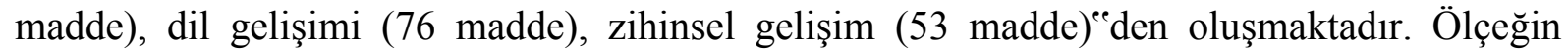

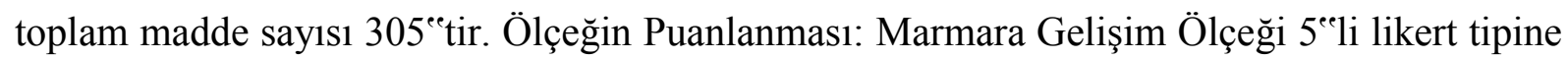
uygun olarak hazırlanmıştır. Buna göre gözlenen her ifade için ham puanların elde edilmesinde bu puanlama yapılmalıdır. Her zaman yapar (5), Çoğunlukla yapar (4), Biraz yapar (3), Çok az yapar (2), Hiç yapamaz (1). Çocuk her ölçek ile ilgili yapılan gözlem ifadelerine göre puan alır ve bu puanların toplamı ham puanları oluşturur. Her ölçekten aldığı puanlar toplanır ve alt ölçeklerin toplam puanı elde edilir. Ölçeğin teorik yapısında yer alan 6 boyutun ayrı birer alt ölçek olarak geliştirilmesi düşünüldüğünden her alt ölçekle ilgili geçerlik ve güvenirlik analizleri ayrı ayrı yapılmıştır. Ölçeğin alt ölçeklerinin iç tutarlılık katsayısı .76-.97 arasındadır. Test ve tekrar test toplam puanları arasında yapılan korelâsyon testi, $\mathrm{r}=0.29$ ile 0.05 anlamlılık düzeyinde bir sonuç vermiştir. Madde analizleri için yapılan iç tutarlık hesaplamaları sonucunda ölçeğin Cronbach Alfa değeri 0.89 olarak bulunmuştur. Maksimum 0.89 güvenirliğe sahip ölçek, minimum 0.87 güvenirliğe sahiptir. Bu sonuçlar ölçeğin geçerli ve güvenilir olduğunu gösterir. Yapılan madde toplam ve madde ayırt edicilik analizleri sonucunda ölçekteki tüm maddelerin 0.01 düzeyinde anlamlı sonuçlar verdiği gözlenmiş ve ölçekten madde atılmamıştır (Ceylan, 2012; Oktay ve Aydın, 2002).

\subsection{Veri Toplama Süreci}

Çalışmanın yapılabilmesi için gerekli izinler İstanbul Valiliği İl Milli Eğitim Müdürlüğü’nden alınmıştır. Belirlenen okullar araştırmacı tarafından ziyaret edilerek okul yöneticisi ve öğretmenlerine çalışma ile ilgili bilgi verilmiş ve araştırmanın çalışma grubunu oluşturan çocuklar ile uygulama öncesinde tanışılmıştır. Çocukların ailelerinden uygulama için izin istenmiş olup çocukların mahremiyetlerine dikkat edilerek çalışma sürdürülmüştür. Genel uygulamalara başlamadan önce 30 çocukla ölçme aracının pilot uygulaması yapılmış; ancak bu 
çocuklarla yapılan uygulamalar veri setine dahil edilmemiştir. Ölçek, hedeflenen çalışma grubunda yer alan çocuklarla birebir uygulanmıştır. Uygulamalar okul yönetimi tarafindan araştırmacıya gösterilen, çocukların dikkatini dağıtmayacak niteliğe sahip, sınıf dışarısında yer alan ayrı bir alanda (okul aile birliği odası, toplantı odası gibi) gerçekleştirilmiştir. Ölçeğin uygulama süresi çocuğun yaşı ve performansına göre ortalama 1.5 saat sürer. Maddelerin sayıca fazla olması nedeniyle dikkati dağılan yada sıkılan çocuklarla ara verilerek gerekirse birkaç gün sonra tekrar kalınan yerden devam edilerek ölçek tamamlanmıştır. Ölçek uygulaması sonunda, her bir çocuğa teşekkür edilerek sınıflarına dönmeleri için eşlik edilmiştir.

Araştırmanın verileri, çalışma grubunu oluşturan çocuklar ile "LAP-3 Gelişim Değerlendirme Ölçeği” kullanarak yapılan birebir çalışmalarla toplanmış olup kişisel bilgilerine ilişsin veriler çocukların ailelerinin okul kaydı sırasında kayıt formlarında beyan ettiği demografik bilgilerle elde edilmiştir. Bunun yanı sıra uygulamaların yapıldığı okullardan biri araştırmacı tarafından seçilerek bu okulda eğitim gören ve rastgele olarak seçilen 60 çocuğa "Marmara Gelişim Ölçeği” uygulanmıştır. Uygulamaların tamamlanmasının ardından tüm formlar incelenmiş ve eksik bilgilerin olduğu formlar araştırmanın verileri arasına dahil edilmemiştir.

\subsection{Verilerin Analizi}

Elde edilen veriler SPSS 16 paket programı aracılığıyla analiz edilmiş ve çözümlenmiştir. Büyük gruplar üzerinden toplanan verilerin, normal dağılıma yakın dağılım gösterdikleri kabul edilebilir ve buna göre parametrik istatistikler seçilebilir. Dağılımın normal dağılımdan aşırı sapma göstermediği şeklinde bir varsayımı ileri sürmek için öngörülen örneklem büyüklüğü genellikle 30 ve daha büyük olarak gösterilmektedir. Parametrik istatistikler dağılımın normalliği varsayımını gerekli kılmaktadır (Büyüköztürk, 2017). Araştırmanın çalışma grubunun 351 çocuktan oluşması bu yönüyle parametrik istatistikler kullanmayı gerektirir. Ancak yapılan normallik testi (Shapiro Wilk-W Testi) sonucunda normal dağılım olmadığ tespit edildiği için nonparametrik istatistikler kullanılmıştır (Tablo 2). 
Tablo 2. LAP-3 Gelişim Değerlendirme Ölçeği Alt Testlerine ilişkin Shapiro Wilk-W Testi Sonuçları.

\begin{tabular}{llll}
\hline Alt testler & İstatistik & SD & p \\
\hline Kaba Motor & .815 & 351 & $.000^{*}$ \\
İnce Motor & .662 & 351 & $.000^{*}$ \\
Okuma Yazmaya Hazırlık & .825 & 351 & $.000^{*}$ \\
Bilisssel & .894 & 351 & $.000^{*}$ \\
Dil & .885 & 351 & $.000^{*}$ \\
Özbakım & .807 & 351 & $.000^{*}$ \\
Kişisel/Sosyal & .717 & 351 & $.000^{*}$ \\
\hline
\end{tabular}
$* \mathrm{p}<0.05$

Ölçeğin geçerlik güvenirlik çalışmaları ile ilgili olarak aşağıdaki istatistiksel işlem ve analizler gerçekleştirilmiştir.

Geçerlik;

- İngilizce formun Türkçe 'ye çevirisinin Türkçe dil uzmanları tarafından incelenmesi, Türkçe formun tekrar İngilizce 'ye çevrilerek İngilizce dil uzmanları tarafından tekrar incelenerek gerekli düzenlemelerin yapılması ve ardından yedi alan uzmanı tarafından çalışma grubuna uygunluğu açısından incelenmesi çeviri ters çeviri yoluyla kapsam geçerliği bakımından önemli bir katkıdır.

- LAP-3 Gelişim Değerlendirme Ölçeği alt testlerinin yap1 geçerliliği açısından değerlendirmesi amacıyla yaşlara göre her birinin birbiri ile ilişkisinin sıfır sıralı order ve kısmı korelasyon analizleri yapılmıştır.

- LAP-3 Gelişim Değerlendirme Ölçeği’nin alt testlerinin kriter geçerliğini sınamak amacıyla Türkiye'de kullanılan ve geçerlik-güvenirliği yapılmış olan Marmara Gelişim Ölçeği ile korelasyonu incelenmiştir.

\section{Güvenirlik;}

- LAP-3 Gelişim Değerlendirme Ölçeği alt testlerinin güvenirliği için alt test puanları ile kronolojik yaş arasındaki korelasyon katsayıları, ortalamalar ve standart sapma puanları hesaplanmıştır.

- LAP-3 Gelişim Değerlendirme Ölçeği alt testlerinin güvenirliği iç tutarlılık katsayısının (Kuder Richardson 20) hesaplanmasıyla elde edilmiştir.

- LAP-3 Gelişim Değerlendirme Ölçeği alt testlerinin güvenirliği için alt testlerden elde edilen puanların yaşa göre ölçmenin standart hata puanları hesaplanmıştır.

- LAP-3 Gelişim Değerlendirme Ölçeği alt testlerinin test tekrar test güvenirliği için korelasyon katsayıları hesaplanmıştır.

- LAP-3 Gelişim Değerlendirme Ölçeği için hakemler arası korelasyon katsayısı hesaplanmıştır. 


\section{BULGULAR}

Bu bölümde 48-72 aylık çocuklar için LAP-3 Gelişim Değerlendirme Ölçeği'nin geçerlik ve güvenirliğine ilişkin bulgular yer almaktadır.

\section{LAP-3 Gelişim Değerlendirme Ölçeği'nin Geçerliğine İlişkin Bulgular}

Bu kısımda LAP-3 Gelişim Değerlendirme Ölçeği ve alt testlerinin yap1 geçerliği ve kriter geçerliğine ilişkin bulgulara yer verilmiştir.

LAP-3 Gelişim Değerlendirme Ölçeği alt testlerinin yapı geçerliği açısından değerlendirilmesi amacıyla yaşlara göre her bir alt testin birbiri ile ilişkinin sıfır sıralı ve kısmı korelasyon analizine ilişkin bulgular Tablo 3'te verilmiştir.

Tablo 3. Çalışma grubunu oluşturan çocukların LAP-3 Gelişim Değerlendirme Ölçeği alt testlerinden aldıkları puanların yaş değiş̧kenine göre Sıfır Sıralı ve Kısmı Korelasyon Analizi Sonuçları

\begin{tabular}{lccccccc}
\hline Alt testler & $\begin{array}{l}\text { Kaba } \\
\text { Motor }\end{array}$ & $\begin{array}{l}\text { İnce } \\
\text { Motor }\end{array}$ & $\begin{array}{l}\text { Okuma } \\
\text { Yazmaya } \\
\text { Hazırlık }\end{array}$ & Bilişsel & Dil & Özbakım & $\begin{array}{l}\text { Kişisel/ } \\
\text { Sosyal }\end{array}$ \\
\hline Kaba Motor & & .36 & .22 & .27 & .23 & .58 & .35 \\
$\begin{array}{l}\text { İnce Motor } \\
\begin{array}{l}\text { Okuma Yazmaya } \\
\text { Hazırlık }\end{array}\end{array}$ & .73 & & .38 & .43 & .32 & .49 & .50 \\
Bilişsel & .71 & .89 & & .64 & .55 & .34 & .23 \\
Dil & .80 & .82 & .86 & & .52 & .25 & .26 \\
Özbakım & .77 & .79 & .78 & .83 & & .38 & .31 \\
Kişisel/Sosyal & .79 & .71 & .71 & .72 & .72 & & .41 \\
\hline *p $<0.001$ & .69 & .74 & .73 & .70 & .71 & .71 & \\
\hline
\end{tabular}

Tablo 3.’e bakıldığında yaş değişkenine göre Sıfır Sıralı Korelasyon sonuçlarının .69 ila .89 arasında değiştiği görülmekte ve bu değerler LAP-3 Gelişim Değerlendirme Ölçeği’nin tek bir temel yapıya sahip olduğunu göstermekte olduğu ayrıca çocukların yaşlarının bir sonucu olarak beceri performanslarındaki farklılıklara işaret ettiği söylenebilir. $\mathrm{Bu}$ durumun ayrımına net olarak varabilmek amacıyla yaşı kontrol altında tutarak alt test toplam puanları üzerinden hesaplanan kısmi korelasyon sonucunun sıfır sıralı korelasyon sonuçlarına göre daha düşük oldukları (.22-.64) ve bu durumun LAP-3 Gelişim Değerlendirme Ölçeği’nin alt testlerinin birbirleriyle hem ilişkili olduğu hem de gelişimin farklı alanlarını ölçtügü yargısına varılmasını sağladığı görülmektedir.

LAP-3 Gelişim Değerlendirme Ölçeği alt testleri ve Marmara Gelişim Ölçeği alt testlerinin kriter geçerliğine ilişkin bulgular Tablo 4 'te sunulmaktadır. 
Tablo 4. Çalışma grubunu oluşturan çocukların LAP-3 Gelişim Değerlendirme Ölçeği (LAP-3) ile Marmara Geliş̧im Ölçeği (MGÖ)'nden aldıkları puanlar arasındaki iliş̧ki ile ilgili Pearson Çarpım Momentler Korelasyon Katsayısı Sonuçları (n=60).

\begin{tabular}{|c|c|c|c|c|c|c|c|}
\hline & & $\begin{array}{c}\text { MGÖ } \\
\text { Bedensel } \\
\text { Gelişim Alt } \\
\text { Testi }\end{array}$ & $\begin{array}{c}\text { MGÖ } \\
\text { Özbakım } \\
\text { Becerileri } \\
\text { Alt Testi }\end{array}$ & $\begin{array}{c}\text { MGO } \\
\text { Duygusal } \\
\text { Gelişim Alt } \\
\text { Testi }\end{array}$ & $\begin{array}{c}\text { MGÖ } \\
\text { Sosyal } \\
\text { Gelişim Alt } \\
\text { Testi }\end{array}$ & $\begin{array}{c}\text { MGÖ } \\
\text { Dil } \\
\text { Gelişimi } \\
\text { Alt Testi }\end{array}$ & $\begin{array}{c}\text { MGÖ } \\
\text { Zihinsel } \\
\text { Gelişim Alt } \\
\text { Testi }\end{array}$ \\
\hline \multirow{3}{*}{$\begin{array}{l}\text { LAP-3 Kaba } \\
\text { Motor Gelişim Alt } \\
\text { Testi }\end{array}$} & $\mathrm{r}$ & $.921^{* *}$ & $.810^{* *}$ & $.712^{* *}$ & $.788^{* *}$ & $.723^{* *}$ & $.753^{* *}$ \\
\hline & $\mathrm{p}$ & .000 & .000 & .000 & .000 & .000 & .000 \\
\hline & $\mathrm{n}$ & 60 & 60 & 60 & 60 & 60 & 60 \\
\hline \multirow{3}{*}{$\begin{array}{l}\text { LAP-3 İnce } \\
\text { Motor Gelişim Alt } \\
\text { Testi }\end{array}$} & $\mathrm{r}$ & $.908^{* *}$ & $.831^{* *}$ & $.723^{* *}$ & $.738^{* *}$ & $.719^{* *}$ & $.821^{* *}$ \\
\hline & $\mathrm{p}$ & .000 & .000 & .000 & .000 & .000 & .000 \\
\hline & $\mathrm{n}$ & 60 & 60 & 60 & 60 & 60 & 60 \\
\hline \multirow{3}{*}{$\begin{array}{l}\text { LAP-3 Okuma } \\
\text { Yazmaya Hazırlık } \\
\text { Alt Testi }\end{array}$} & $\mathrm{r}$ & $.842^{* *}$ & $.784^{* *}$ & $.702^{* *}$ & $.738^{* *}$ & $.809^{* *}$ & $.869^{* *}$ \\
\hline & $\mathrm{p}$ & .000 & .000 & .000 & .000 & .000 & .000 \\
\hline & $\mathrm{n}$ & 60 & 60 & 60 & 60 & 60 & 60 \\
\hline \multirow{3}{*}{$\begin{array}{l}\text { LAP-3 Bilişsel } \\
\text { Gelişim Alt Testi }\end{array}$} & $\mathrm{r}$ & $.814^{* *}$ & $.794^{* *}$ & $.738^{* *}$ & $.766^{* *}$ & $.796^{* *}$ & $.878^{* *}$ \\
\hline & $\mathrm{p}$ &, 000 & .000 & .000 & .000 & .000 & .000 \\
\hline & $\mathrm{n}$ & 60 & 60 & 60 & 60 & 60 & 60 \\
\hline \multirow{3}{*}{$\begin{array}{l}\text { LAP-3 Dil Gelişim } \\
\text { Alt Testi }\end{array}$} & r & $.787^{* *}$ & $.762^{* *}$ & $.749^{* *}$ & $.761^{* *}$ & $.811^{* *}$ & $.697^{* *}$ \\
\hline & $\mathrm{p}$ & .000 & .000 & .000 & .000 & .000 & .000 \\
\hline & $\mathrm{n}$ & 60 & 60 & 60 & 60 & 60 & 60 \\
\hline \multirow{3}{*}{$\begin{array}{l}\text { LAP-3 Özbakım } \\
\text { Becerileri Alt } \\
\text { Testi }\end{array}$} & $\mathrm{r}$ & $.798^{* *}$ & $.925^{* *}$ & $.711^{* *}$ & $.762^{* *}$ & $.723^{* *}$ & $.670^{* *}$ \\
\hline & $\mathrm{p}$ & .000 & .000 & .000 & .000 & .000 & .000 \\
\hline & $n$ & 60 & 60 & 60 & 60 & 60 & 60 \\
\hline \multirow{3}{*}{$\begin{array}{l}\text { LAP-3 Kişisel/ } \\
\text { Sosyal Gelişim Alt } \\
\text { Testi }\end{array}$} & $\mathrm{r}$ & $.715^{* *}$ & $.758^{* *}$ & $.849^{* *}$ & $.843^{* *}$ & $.635^{* *}$ & $.671^{* *}$ \\
\hline & $\mathrm{p}$ & .000 & .000 & .000 & .000 & .000 & .000 \\
\hline & $\mathrm{n}$ & 60 & 60 & 60 & 60 & 60 & 60 \\
\hline
\end{tabular}

$* * \mathrm{p}<0.01$

Tablo 4'e göre LAP-3 Gelişim Değerlendirme Ölçeği alt testleri ile MGÖ alt testleri arasında pozitif yönde ve anlamlı ilişki olduğu bulunmuştur. Tablo incelendiğinde LAP-3 Kaba Motor Gelişim ve İnce Motor Gelişim alt testleri ile MGÖ alt testleri arasında pozitif yönde ve anlamlı bir ilişki bulunmuş olup, en yüksek oranda ilişkinin her iki alt test içinde MGÖ Bedensel Gelişim alt testi ile olduğu görülmüştür ( $\mathrm{r}=.921, \mathrm{p}<0.01 ; \mathrm{r}=.908, \mathrm{p}<0.01$ ). MGÖ Bedensel Gelişim alt testinin ölçmesi beklenilen gelişimsel beceriler ile LAP-3 Kaba ve İnce Motor gelişim alt testlerinin ölçmesi beklenilen gelişimsel becerilerin birbiriyle uyumlu olduğundan kaynaklı bu sonuca ulaşıldığı söylenebilir.

LAP-3 Okuma yazmaya hazırlık alt testi ile MGÖ alt testleri arasındaki ilişkiye bakıldığında en yüksek oranda ilişkinin başta MGÖ Bilişsel Gelişim alt testi $(r=.869, p<0.01)$ olmak üzere sırasıyla MGÖ Bedensel Gelişim ( $\mathrm{r}=842, \mathrm{p}<0.01)$ ve MGÖ Dil Gelişimi $(\mathrm{r}=.809, \mathrm{p}<0.01)$ alt testleri ile olduğu görülmektedir. Okuma yazmaya hazırlık kapsamında çocukların bilişsel, dil 
ve bedensel gelişim açısından belirli bir düzeyde hazırbulunuşluğa sahip olmaları gerektiği göz önüne alındığında LAP-3 Okuma Yazmaya Hazırlık alt testi ile MGÖ Bilişsel, Dil ve Bedensel Gelişim alt testleri arasında yüksek düzeyde ilişkinin olmasının beklenilen bir sonuç olduğu söylenebilir.

LAP-3 Bilişsel gelişim alt testi ile MGÖ alt testleri arasında ilişki incelenmiş en yüksek oranda ilişkinin MGÖ Bilişsel gelişim testi ile olduğu görülmüştür. Bu ilişkinin pozitif yönlü ve yüksek düzeyde anlamlı olduğu bulunmuştur $(\mathrm{r}=.878, \mathrm{p}<0.01)$. LAP-3 Dil gelişimi alt testi ile MGÖ Dil gelişimi alt testi arasında pozitif yönde ve yüksek düzeyde anlamlı ilişki olduğu bulunmuştur $(\mathrm{r}=.811, \mathrm{p}<0.01)$. LAP-3 Özbakım Becerileri alt testi ile en yüksek oranda ilişkisi olan MGÖ Özbakım Becerileri alt testidir. Mevcut anlamlı ilişkinin pozitif yönlü ve yüksek düzeyde olduğu görülmüştür $(r=.925, \mathrm{p}<0.01)$. LAP-3 Kişisel/Sosyal gelişim alt testi ile MGÖ Sosyal gelişim alt testi arasında pozitif yönde ve yüksek düzeyde anlamlı bir ilişki olduğu bulunmuştur $(\mathrm{r}=.843, \mathrm{p}<0.01)$.

Kriter geçerliliği kapsamında yapılan analizler sonucunda elde edilen bulguların LAP-3 Gelişim Değerlendirme Ölçeği ile Marmara Gelişim Ölçeği’nin çocukların gelişimlerini benzer kriterler kullanarak değerlendirdikleri bu nedenle de alt testler arasında yüksek düzeyde, anlamlı ve pozitif bir ilişkinin görüldüğü söylenebilir.

\section{LAP-3 Gelişim Değerlendirme Ölçeği’nin Güvenirliğine Illişkin Bulgular}

Bu kısımda LAP-3 Gelişim Değerlendirme Ölçeği’nin güvenirliğine ilişkin yapılan kronolojik yaş ile alt testler arası korelasyon, iç tutarlılık, ölçmenin standart hatası, test tekrar test ve hakemler arası güvenirlik analizi bulguları sunulmaktadır. LAP-3 Gelişim Değerlendirme Ölçeği alt testleri ile kronolojik yaş arasındaki ilişki ile ilgili olarak yapılan korelasyon analizi sonuçları, aritmetik ortalama ve standart sapma değerleri Tablo 5'te sunulmaktadır. Yapılan normallik testi (Kolmogorov Smirnov Testi) sonucunda normal dağılım olmadığı tespit edildiği için Spearman Brown Sıra Farkları Katsayısı Testi kullanılmıştır.

Tablo 5. Çalı̧̧ma grubunu oluşturan çocukların LAP-3 Gelişim Değerlendirme Ölçeği Alt testlerinden aldıkları puanların yaşa göre farklılaşma durumlarına ilişskin Aritmetik Ortalama, Standart Sapma ve Spearman Brown Sira Farkları Katsayısı Sonuçları

\begin{tabular}{lccc}
\hline $\begin{array}{l}\text { LAP-3 Gelişim Değerlendirme Ölçeği } \\
\text { Alt Testler }\end{array}$ & $\overline{\mathrm{X}}$ & $\mathbf{S s}$ & $\mathbf{r}$ \\
\hline Kaba Motor Gelişim & 46,98 & 7,40 & .70 \\
İnce Motor Gelişim & 37,98 & 3,11 & .81 \\
Okuma Yazmaya Hazırlık & 32,33 & 5,63 & .79 \\
Bilişsel Gelişim & 70,80 & 13,45 & .82 \\
Dil Gelişimi & 56,31 & 9,78 & .74 \\
Özbakım Becerileri & 45,73 & 4,81 & .73 \\
Kişisel/Sosyal Gelişim & 42,13 & 3,08 & .68 \\
$\mathrm{p}<0.01$ & & &
\end{tabular}


Çalışma grubunu oluşturan çocukların LAP-3 Gelişim Değerlendirme Ölçeği alt testlerinden aldıkları puanlar ile kronolojik yaşları arasındaki korelasyona ilişkin sonuçların sunulduğu Tablo 5'e göre yedi alt testin altısından elde edilen puanlar ile kronolojik yaş arasında pozitif yönde ve yüksek düzeyde (.70-.82), Kişisel/Sosyal gelişim alt testinden elde edilen puanlar ile kronolojik yaş arasında pozitif yönde ve orta düzeyde (.68) bir ilişki olduğu görülmüştür. Buna göre çocukların alt testlerden aldıkları toplam puanların kronolojik yaşları ile yüksek düzeyde ilişkili olduğu ve yaşı daha büyük olan çocukların yaşı daha küçük olanlara oranla daha yüksek puanlar elde edeceği söylenebilir.

Tablo 6. LAP-3 Gelişsim Değerlendirme Ölçeği Alt Testlerinin Yaşlara Göre İç Tutarlıllk Güvenirliğine İlişkin Kuder Richardson 20 Analizi Sonuçları.

\begin{tabular}{lccccc}
\hline Alt Test & $\mathbf{4 8 - 5 3} \mathbf{A y}$ & $\mathbf{5 4 - 5 9} \mathbf{A y}$ & $\mathbf{6 0 - 6 5} \mathbf{A y}$ & $\mathbf{6 6 - 7 2} \mathbf{A y}$ & $\mathbf{4 8 - 7 2} \mathbf{A y}$ \\
\hline Kaba Motor Gelişim & .93 & .93 & .86 & .78 & .94 \\
İnce Motor Gelişim & .90 & .85 & .76 & .91 & .92 \\
Okuma Yazmaya Hazırlık & .90 & .93 & .88 & .72 & .93 \\
Bilişsel Gelişim & .97 & .96 & .93 & .95 & .97 \\
Dil Gelişimi & .95 & .93 & .97 & .97 & .98 \\
Özbakım Becerileri & .92 & .85 & .88 & .91 & .96 \\
Kişisisel/Sosyal Gelişim & .86 & .79 & .78 & .70 & .91 \\
\hline
\end{tabular}

Tablo 6'da LAP-3 Gelişim Değerlendirme Ölçeği alt testlerinin yaşlara göre iç tutarlılık güvenirliğine ilişskin sonuçlar verilmiştir. 48-53 ay için iç tutarlılık katsayıları Kaba Motor .93, İnce Motor .90, Okuma Yazmaya Hazırlık, .90, Bilişsel, .97, Dil .95, Özbakım .92 ve Kişisel/Sosyal Gelişim .86 olarak bulunmuştur. 54-59 ay için iç tutarlılık katsayıları Kaba Motor .93, İnce Motor .85, Okuma Yazmaya Hazırlık .93, Bilişsel .96, Dil .93, Özbakım .85 ve Kişisel/Sosyal Gelişim .79 olarak bulunmuştur. 60-65 ay için Kaba Motor .86, İnce Motor .76, Okuma Yazmaya Hazırlık .88, Bilişsel .93, Dil .97, Özbakım .88 ve Kişisel/ Sosyal Gelişim .78 olarak bulunmuştur. 66-72 ay için Kaba Motor .78, İnce Motor .91, Okuma Yazmaya Hazırlık .72, Bilişsel . 95, Dil . 97, Özbakım . 91 ve Kişisel/Sosyal Gelişim .70 olarak bulunmuştur. Ölçeğin geneli için iç tutarlılık katsayısının .91 ila .98 arasında alt testlere göre değiştiği bulunmuştur. LAP-3 Gelişim Değerlendirme Ölçeği için hesaplanan iç tutarlılık katsayılarının hem yaş gruplarında hem de genelinde ölçme aracının iç tutarlılığının yüksek olduğu söylenebilir.

Tablo 7. LAP-3 Gelişim Değerlendirme Ölçeği Alt Testlerinin Yaşlara Göre Ölçmenin Standart Hata Puanlarına İliş̧kin Sonuçları.

\begin{tabular}{llcccc}
\hline Alt Test & min & max & $\overline{\mathbf{x}}$ & $\begin{array}{c}\text { Standart } \\
\text { Hata }\end{array}$ \\
\hline 48-53 Ay & Kaba Motor Gelişim & 20 & 52 & 36,12 & 2.40 \\
& İnce Motor Gelişim & 25 & 40 & 33,95 & 1.60 \\
& Okuma Yazmaya Hazırlık & 20 & 36 & 24,23 & 1.50 \\
& Bilişsel Gelişim & 33 & 82 & 55,55 & 2.50
\end{tabular}




\begin{tabular}{|c|c|c|c|c|c|}
\hline & Dil Gelisimi & 29 & 58 & 39,29 & 2.08 \\
\hline & Özbakım Becerileri & 29 & 48 & 38,25 & 1.68 \\
\hline & Kişisel/Sosyal Gelişim & 25 & 44 & 38,23 & 1.97 \\
\hline \multirow[t]{7}{*}{ 54-59 Ay } & Kaba Motor Gelişim & 28 & 54 & 42,04 & 1.99 \\
\hline & İnce Motor Gelişim & 25 & 40 & 36,40 & 1.37 \\
\hline & Okuma Yazmaya Hazırlık & 20 & 38 & 28,18 & 1.67 \\
\hline & Bilişsel Gelişim & 36 & 86 & 64,28 & 2.94 \\
\hline & Dil Gelişimi & 39 & 69 & 51,0 & 2.17 \\
\hline & Özbakım Becerileri & 37 & 50 & 42,69 & 1.44 \\
\hline & Kişisel/Sosyal Gelişim & 32 & 45 & 41,81 & 1.21 \\
\hline \multirow[t]{7}{*}{ 60-65 Ay } & Kaba Motor Gelişim & 36 & 54 & 48,46 & 1.55 \\
\hline & İnce Motor Gelişim & 33 & 40 & 38,34 & .79 \\
\hline & Okuma Yazmaya Hazırlık & 21 & 38 & 33,47 & 1.39 \\
\hline & Bilişsel Gelişim & 54 & 86 & 70,47 & 2.83 \\
\hline & Dil Gelişimi & 47 & 69 & 58,34 & .88 \\
\hline & Özbakım Becerileri & 39 & 50 & 46,57 & 1.03 \\
\hline & Kişisel/Sosyal Gelişim & 35 & 45 & 42,46 & .94 \\
\hline \multirow[t]{7}{*}{ 66-72 Ay } & Kaba Motor Gelişim & 44 & 54 & 51,43 & 1.09 \\
\hline & İnce Motor Gelişim & 36 & 40 & 39,70 & .17 \\
\hline & Okuma Yazmaya Hazırlık & 32 & 38 & 35,80 & 1.02 \\
\hline & Bilişsel Gelişim & 61 & 86 & 79,37 & 1.59 \\
\hline & Dil Gelişimi & 53 & 69 & 62,65 & .67 \\
\hline & Özbakım Becerileri & 41 & 50 & 48,85 & .45 \\
\hline & Kişisel/Sosyal Gelişim & 38 & 45 & 43,38 & .83 \\
\hline \multirow[t]{7}{*}{ 48-72 AY } & Kaba Motor Gelişim & 20 & 54 & 46,98 & 1.77 \\
\hline & İnce Motor Gelişim & 25 & 40 & 37,97 & .87 \\
\hline & Okuma Yazmaya Hazırlık & 20 & 38 & 32,33 & 1.46 \\
\hline & Bilişsel Gelişim & 33 & 86 & 70,80 & 2.28 \\
\hline & Dil Gelişimi & 29 & 69 & 56,31 & 1.37 \\
\hline & Özbakım Becerileri & 29 & 50 & 46,73 & .96 \\
\hline & Kişisel/Sosyal Gelişim & 25 & 45 & 42,13 & .92 \\
\hline
\end{tabular}

Tablo 7'de LAP-3 Gelişim Değerlendirme Ölçeği alt testlerinin çocukların yaşlarına göre ölçmenin standart hata puanlarının analizine ilişkin sonuçlar sunulmaktadır. 48-53 aylık çocuklar için ölçmenin standart hata puanları 1.50 ile 2.50 arasında; $54-59$ aylık çocuklar için 1.21 ile 2.94 arasında; 60-65 aylık çocuklar için .79 ile 2.83 arasında; 66-72 aylık çocuklar için .17 ile 1.59 arasında; 48-72 aylık çocuklar için .87 ile 2.28 arasında değiştiği bulunmuştur. Ölçmenin standart hata puanı çocukların gerçek puanları ile gözlenen puanları arasındaki hata payını ölçmek amacıyla hesaplanmakta ve güvenirlik ile ters oranlı ilişki göstermektedir. Ölçme aracının güvenirlik oranı arttıkça ölçmenin standart hata puanları o derece düşük olacağından bu durum gözlenen puanların doğruluğuna olan güveni arttıracaktır (Young, Kane, Nicholson ve Schuman, 2007; s. 39). 
Tablo 8. LAP-3 Gelişim Değerlendirme Ölçeği alt testlerinin Test Tekrar Test Güvenirliğine İlişkin Ortalama, Standart Sapma ve Korelasyon Sonuçları $(n=60)$

\begin{tabular}{|c|c|c|c|c|c|}
\hline & \multicolumn{2}{|c|}{ Test } & \multicolumn{2}{|c|}{ Tekrar Test } & \multirow[b]{2}{*}{$\mathbf{r}$} \\
\hline & $\overline{\mathrm{x}}$ & Ss & $\overline{\mathrm{x}}$ & Ss & \\
\hline Kaba Motor Gelişim & 45,65 & 8,970 & 46,32 & 8,750 & $.99^{* *}$ \\
\hline İnce Motor Gelişim & 36,65 & 4,964 & 37,17 & 4,431 & $.93^{* *}$ \\
\hline Okuma Yazmaya Hazırlık & 30,68 & 6,900 & 31,53 & 7,022 & $.98^{* *}$ \\
\hline Bilişsel Gelişim & 67,00 & 15,225 & 68,08 & 15,117 & $.99^{* *}$ \\
\hline Dil Gelişimi & 54,95 & 12,123 & 55,43 & 12,217 & $.99^{* *}$ \\
\hline Özbakım Becerileri & 43,63 & 6,410 & 43,92 & 6,339 & $.99^{* *}$ \\
\hline Kişisel/Sosyal Gelişim & 41,07 & 4,166 & 41,48 & 4,011 & $.98^{* *}$ \\
\hline
\end{tabular}

$$
* * \mathrm{p}<0.01
$$

Tablo 8'e göre LAP-3 Gelişim Değerlendirme Ölçeği alt testlerinin test tekrar test güvenirliğine ilişkin korelasyon katsayısı analizi sonucuna göre pozitif yönde ve yüksek düzeyde anlamlı bir ilişki olduğu görülmüştür (.93-.99). Bu sonuçlara göre ölçme aracının test tekrar test güvenirliğinin kabul edilebilir düzeyde olduğunu söylenebilir.

Tablo 9. LAP-3 Gelişim Değerlendirme Ölçeği'nin Uygulayıcılar Arası Korelasyonu

\begin{tabular}{|c|c|c|c|c|c|c|c|}
\hline $\begin{array}{l}\text { LAP-3 Gelişim } \\
\text { Değerlendirme } \\
\text { Ölçeği Alt Testleri }\end{array}$ & $\begin{array}{c}\text { U2 } \\
\text { Kaba } \\
\text { Motor }\end{array}$ & $\begin{array}{c}\text { U2 } \\
\text { İnce Motor }\end{array}$ & $\begin{array}{c}\text { U2 } \\
\text { Okuma } \\
\text { Yazmaya } \\
\text { Hazırlık } \\
\end{array}$ & $\begin{array}{c}\text { U2 } \\
\text { Bilişsel }\end{array}$ & $\begin{array}{l}\text { U2 } \\
\text { Dil }\end{array}$ & $\begin{array}{c}\mathrm{U} 2 \\
\text { Özbakım } \\
\text { Becerileri }\end{array}$ & $\begin{array}{c}\text { U2 } \\
\text { Kişisel/ } \\
\text { Sosyal }\end{array}$ \\
\hline U1 Kaba Motor & $.883(* *)$ & - & - & - & - & - & - \\
\hline U1 İnce Motor & - & $.934(* *)$ & - & - & - & - & - \\
\hline $\begin{array}{l}\text { U1 Okuma Yazmaya } \\
\text { Hazırlık }\end{array}$ & - & - & $.947(* *)$ & - & - & - & - \\
\hline U1 Bilişsel & - & - & - & $.959(* *)$ & - & - & - \\
\hline U1 Dil & - & - & - & - & $.914(* *)$ & - & - \\
\hline U1Özbakım Becerileri & - & - & - & - & - & $.826(* *)$ & - \\
\hline U1 Kişisel/Sosyal & - & - & - & - & - & - & $.967(* *)$ \\
\hline
\end{tabular}

Tablo 9'a göre LAP-3 Gelişim Değerlendirme Ölçeği alt testlerinin Uygulayıcı 1 ve Uygulayıcı 2 tarafından yapılan uygulamalar arasındaki ilişki Pearson Korelasyon katsayısı hesaplanarak incelenmiştir. Uygulayıcılar arası güvenirliğin hesaplanabilmesi için LAP-3 Gelişim Değerlendirme Ölçeği iki okul öncesi eğitim uzmanı (okul öncesi eğitim alanında yüksek lisans derecesine sahip) tarafından 1 hafta arayla kodlanmıştır. Ölçeğin alt testlerine ait Uygulayıcı 1 ve Uygulayıcı 2 tarafından yapılan kodlamaların ilişkisi Pearson Korelasyon Katsayısı hesaplanarak incelenmiştir. Buna göre kaba motor alt testinde uygulayıcılar arası korelasyon katsayıs1 $.88(\mathrm{p}=.000)$, ince motor alt testinde $.93(\mathrm{p}=.000)$, okuma yazmaya hazırlık alt testinde $.94(p=.000)$, bilişsel alt testinde $.95(p=.000)$, dil alt testinde $.91(p=.000)$, özbakım 
alt testinde $.82(\mathrm{p}=.000)$, kişisel/sosyal alt testinde $.96(\mathrm{p}=.000)$, olmak üzere pozitif yönlü yüksek dereceli ilişki olduğu görülmektedir $(n=30)$.

\section{SONUÇ VE TARTIŞMA}

48-72 aylık çocuklar için LAP-3 Gelişim Değerlendirme Ölçeği’nin geçerlik ve güvenirlik çalışmasının yapılmasını amaçlayan bu araştırmaya ilişkin sonuçlar ve tartışma bu bölümde sunulmaktadır. Bu araştırmada geçerlik çalışmaları kapsamında LAP-3 Gelişim Değerlendirme Ölçeği'nin orijinalinde yer alan geçerlik çalışmaları temel alınmış olup bu çalışmalar Büyüköztürk (2017, s. 179-181) ve Standards for Educational and Psychological Testing (1999; Akt. Hardin ve Feisenberg, 2004, s. 38)'de belirtilen geçerlik sınıflandırmalarıyla örtüşür.

LAP-3 Gelişim Değerlendirme Ölçeği'nin geçerlik çalışmaları kapsamında ilk olarak kapsam geçerliği çalışmaları yapılmıştır. LAP-3 Gelişim Değerlendirme Ölçeği'nin uzman görüşüne gönderilmesinden önce dil geçerliliği çalışmaları kapsamında ölçeğin İngilizce ‘den Türkçe ‘ye çevirisi yapılmış ve Türkçe dil uzmanları tarafından incelenmiştir. Türkçe dil uzmanlarının önerileri doğrultusunda yapılan düzeltmelerin ardından ölçeğin Türkçe formu tekrar İngilizce 'ye çevrilerek dil alan uzmanları tarafından her iki İngilizce formun kontrolleri yapılmıştır. Çevirinin ardından kapsam geçerliği için okul öncesi eğitim konusunda 7 alan uzmanına ölçeğin orijinali ve Türkçe çeviri hali gönderilmiş ve uygulanacak çalışma grubuna uygunluğu açısından alan uzmanlarından görüş istenmiştir. Alan uzmanlarından gelen görüşler doğrultusunda ölçek tekrar gözden geçirilerek düzenlenmiş ve Türkçe Formu'na son hal verilmiştir. Gelen uzman görüşleri doğrultusunda son hal verilen Türkçe formun 30 çocukla pilot uygulaması yapılmıştır. Ancak bu çocuklarla yapılan uygulamalar veri setine dahil edilmemiştir. Pilot uygulamalarda yönergelerin açık ve anlaşılır olması, ölçeğin çocuklara sunuş şekli ve uygulama esnasında yaşanabilecek olası sorunlar ya da aksaklıklar değerlendirilmiş gerekli önlemler alınmıştır.

Geçerlik çalışmalarının bir diğer adımı olan yapı geçerliği çalışmaları yapılmıştır. LAP-3 Gelişim Değerlendirme Ölçeği'nin yapı geçerliği çalışmaları kapsamında ölçme aracının orijinalinde uygulanan yapı geçerliği analizi Sıfır Sıralı Korelasyon ve Kısmı Korelasyon yoluyla yapılmıştır. Çalışma grubunu oluşturan çocukların kronolojik yaşlarına göre yapılan sıfır sıralı korelasyon sonuçlarının .69 ile .89 arasında değiştiği görülmekte ve bu değerler LAP3 Gelişim Değerlendirme Ölçeği’nin tek bir temel yapıya sahip olduğunu göstermektedir. Ayrıca çocukların yaşlarının bir sonucu olarak beceri performanslarındaki farklılıklara işaret ettiği söylenebilir. Bu durumun ayrımına net olarak varabilmek amacıyla yaşı kontrol altında tutarak alt test toplam puanları üzerinden hesaplanan kısmi korelasyon sonucunun sıfır sıralı 
korelasyon sonuçlarına göre daha düşük oldukları (.22-.64) ve bu durumun LAP-3 Gelişim Değerlendirme Ölçeği'nin alt testlerinin birbirleriyle hem ilişkili olduğu hem de gelişimin farklı alanlarını ölçtüğü yargısına varılmasını sağlamaktadır. Ölçeğin orijinalinde yer alan sıfır sıralı ve kısmi korelasyon analizi sonuçlarının bu araştırmanın sonuçları ile paralellik gösterdiği söylenebilir (Sıfır sıralı korelasyon .61-89; kısmi korelasyon .26- 62). Bu sonuç Senemoğlu (2012, s.6-7)'nun gelişimim temel ilkeleri arasında sıraladığı "Gelişim bir bütündür” ve “Nöbetleşe Devam eder” ilkeleri göz önüne alınarak gelişim alanlarının birbirleriyle hem ilişkili olduğu hem de çocuğun farklı gelişim alanlarında farklı hızlarda ilerleme kat etmesi nedeniyle gelişim alanları arasında farklılıklar olabileceği olarak yorumlanabilir. Gelişimin her bir alanı kendi içinde bir düzen ve hızla ilerlemekte ancak bir gelişim alanında meydana gelen problem yada kriz durumu diğer tüm gelişim alanlarını da etkilemektedir. Bu sebeple gelişim alanları birbirinden ayrı değerlendirmek o alandaki mevcut durumun ortaya konulması açısından gereklidir ancak çocuğun gelişimine ilişkin genel bir yargıya varma açısından sınırlılık yaratmaktadır. Bu nedenle her bir gelişim alanını kendi içinde değerlendirmenin yanı sıra bütün gelişim alanlarını da aynı anda değerlendirmek çocuğun genel durumu ve özelde hangi gelişim alanında ne durumda olduğunun görülmesi açısından önemli ve gereklidir. Yapı geçerliği kapsamında yapılan analizlerin sonuçları da LAP-3 Gelişim Değerlendirme Ölçeği alt testlerinin hem birbirleriyle ilişkili olduğunu hem de her bir alt testin kendine ait bir değerlendirme imkanı sunduğunu ortaya koymaktadır.

Kapsam geçerliği çalışmalarının ardından ölçüt bağımlı geçerlik çalışmalarına başlanmıştır. $\mathrm{Bu}$ araştırma kapsamında ölçüt geçerliği için eşzaman geçerliği tekniği uygulanmış ve LAP-3 Gelişim Değerlendirme Ölçeği ile aynı özellikleri ölçen geçerlik ve güvenirliği yapılmış bir başka ölçme aracı olan Marmara Gelişim Ölçeği kullanılmıştır. 60 çocukla her iki ölçek uygulanarak elde ettikleri puanlar arasındaki Pearson korelasyon katsayıları hesaplanmıştır. LAP-3 Gelişim Değerlendirme Ölçeği alt testlerinin tümü ile MGÖ alt testlerinin tümü arasında pozitif yönde ve ortadan yüksek düzeye doğru değişen bir aralıkta anlamlı ilişki olduğu bulunmuştur. Ayrıca her iki ölçme aracının aynı gelişim alanlarını değerlendiren alt testleri arasında pozitif yönlü ve yüksek düzeyde anlamlı bir ilişki olduğu bulunmuştur. Söz konusun ilişkilerin düzeyleri incelendiğinde .635 ile .948 arasında değişkenlik gösterdiği görülmektedir. Büyüköztürk (2017, s.32) korelasyon katsayısının mutlak değer olarak .70 ile 1.00 arasında olması yüksek, .70 ile .30 arasında olması orta, .30 ile .00 arası ise düşük düzeyde bir ilişki olarak tanımlamaktadır. Bu tanımlamadan hareketle yapılan analiz sonucunda elde edilen değerlerin orta ve yüksek düzeyde olduğu söylenebilir. Değerlerin bir kısmının orta düzeyde 
ilişkili olmasının ise ölçme aracının gelişimin tüm alanlarında değerlendirme yapıyor olması ve gelişimin bir bütün olduğu bilgisinden hareketle birbirlerinden ayrı düşünülemeyeceği, her bir alanın bir diğeriyle belli oranlarda ilişkili olmasından kaynaklı olabileceği düşünülmektedir.

Ölçme araçlarının geçerliğine ilişkin alan yazında yer alan analiz teknikleri uygulanarak geçerliği test edilen LAP-3 Gelişim Değerlendirme Ölçeği'nin 48-72 aylık Türk çocukları için geçerli bir ölçme aracı olduğu söylenebilir.

Bu araştırmada güvenirlik çalışmaları kapsamında LAP-3 Gelişim Değerlendirme Ölçeği'nin orijinalinde yer alan güvenirlik çalışmaları temel alınmış olup bu çalışmalar Balcı (2015, s. 112 113) ve Karasar (2016, s. 148)'ın belirttiği güvenirlik teknikleri ile örtüşmektedir.

LAP-3 Gelişim Değerlendirme Ölçeği'nin güvenirlik çalışmaları kapsamında alt test puanları ile çalışma grubunu oluşturan çocukların kronolojik yaşları arasındaki korelasyon katsayıları, ortalamaları ve standart sapma puanları hesaplanmıştır. Alt testlerden Kişisel/Sosyal Gelişim alt testi dışındaki tüm alt testlerden elde edilen puanlar ile elde edilen puanlar ile kronolojik yaş arasında pozitif yönde ve yüksek düzeyde (.70-.82), Kişisel/Sosyal gelişim alt testinden elde edilen puanlar ile kronolojik yaş arasında pozitif yönde ve orta düzeyde (.68) bir ilişki olduğu görülmüştür. Ölçeğin orijinali için yapılan aynı analiz sonucunda Kişisel/ Sosyal Gelişim alt testi dışındaki tüm alt testlerden elde edilen puanlar ile kronolojik yaş arasında pozitif yönde ve yüksek düzeyde (.77-.84), Kişisel/ Sosyal gelişim alt testinden elde edilen puanlar ile kronolojik yaş arasından pozitif yönde ve orta düzeyde (.61) bir ilişki olduğu görülmüştür (Hardin ve Feisenberg, 2004, s. 34). Bu bağlamda bu araştırmadan elde edilen sonuçlar ile ölçeğin orijinalinden elde edilen sonuçların birbirine paralel olduğu görülmüştür. $\mathrm{Bu}$ sonucun çocukların alt testlerden aldıkları toplam puanlarının kronolojik yaşları ile yüksek düzeyde ilişkili olduğu ve yaşı daha büyük olan çocukların yaşı daha küçük olanlara oranla daha yüksek puanlar elde edeceğini işaret ettiği söylenebilir.

LAP-3 Gelişim Değerlendirme Ölçeği alt testlerinin çocukların yaşlarına göre ölçmenin standart hata puanları hesaplanmıştır. Ölçme aracının güvenirlik oranı arttıkça ölçmenin standart hata puanları o derece düşük olacağından bu durum gözlenen puanların doğruluğuna olan güveni arttıracaktır (Hardin ve Feisenberg, 2004, s. 35). Araştırmalarda kullanılabilecek ölçme araçları için öngörülen güvenirlik düzeyinin .70 ve üzeri olması gerektiği (Büyüköztürk, 2017, s. 182) göz önüne alınırsa LAP-3 Gelişim Değerlendirme Ölçeği’nin alt testlerinin güvenirlik düzeyinin kabul edilebilir değerler arasında ve yüksek olduğu söylenebilir. 
Güvenirlik çalışmaları kapsamında LAP-3 Gelişim Değerlendirme Ölçeği alt testlerinin iç tutarlılık katsayısı hesaplanmıştır. LAP-3 Gelişim Değerlendirme Ölçeği için iç tutarlılık katsayı hesaplanırken maddelere verilecek cevapların 1 ve 0 şeklinde iki seçenekli olmasından dolayı Kuder Richardson-20 güvenirliği kullanılmıştır (Büyüköztürk, 2017, s. 182).

LAP-3 Gelişim Değerlendirme Ölçeği alt testlerinin yaşlara göre iç tutarlılık güvenirliğine ilişkin 48-53 ay için iç tutarlılık katsayıları Kaba Motor .93, İnce Motor .90, Okuma Yazmaya Hazırlık, .90, Bilişsel, .97, Dil .95, Özbakım .92 ve Kişisel/Sosyal Gelişim .86 olarak bulunmuştur. 54-59 ay için iç tutarlılık katsayıları Kaba Motor .93, İnce Motor .85, Okuma Yazmaya Hazırlık .93, Bilişsel .96, Dil .93, Özbakım .85 ve Kişisel/Sosyal Gelişim .79 olarak bulunmuştur. 60-65 ay için Kaba Motor .86, İnce Motor .76, Okuma Yazmaya Hazırlık .88, Bilişsel .93, Dil .97, Özbakım .88 ve Kişisel/ Sosyal Gelişim .78 olarak bulunmuştur. 66-72 ay için Kaba Motor .78, İnce Motor .91, Okuma Yazmaya Hazırlık .72, Bilişsel . 95, Dil . 97, Özbakım . 91 ve Kişisel/Sosyal Gelişim .70 olarak bulunmuştur. Ölçeğin geneli için iç tutarlılık katsayısının .91 ila .98 arasında alt testlere göre değiştiği bulunmuştur.

Ölçeğin orijinali için yapılan iç tutarlılık analiz sonuçlarına bakıldığında 48-53 ay için iç tutarlılık katsayıları Kaba Motor .94, İnce Motor .92, Okuma Yazmaya Hazırlık, .91, Bilişsel, .98, Dil .95, Özbakım .90 ve Kişisel/Sosyal Gelişim .93 olarak bulunmuştur. 54-59 ay için iç tutarlılık katsayıları Kaba Motor .89, İnce Motor .91, Okuma Yazmaya Hazırlık .92, Bilişsel .97, Dil .91, Özbakım .93 ve Kişisel/Sosyal Gelişim .78 olarak bulunmuştur. 60-65 ay için Kaba Motor .94, İnce Motor .91, Okuma Yazmaya Hazırlık .91, Bilişsel .97, Dil .95, Özbakım .91 ve Kişisel/ Sosyal Gelişim 95 olarak bulunmuştur. 66-72 ay için Kaba Motor .89, İnce Motor .92, Okuma Yazmaya Hazırlık .89, Bilişsel . 95, Dil . 97, Özbakım . 91 ve Kişisel/Sosyal Gelişim .85 olarak bulunmuştur. Ölçeğin geneli için iç tutarlılık katsayısının .96 ila .99 arasında alt testlere göre değiştiği bulunmuştur (Hardin ve Feisenberg, 2004, s. 35). Bu araştırmadan elde edilen sonuçlar ile ölçeğin orijinalinde yer alan iç tutarlılık analiz sonuçları incelendiğinde birbirlerine oldukça benzer oldukları görülmektedir. Coolican (2014, s. 217) iç tutarlılık için güvenirlik katsayının .75 ila 1 arasında olması gerektiğini; Johnson ve Christensen (2014, s. 142) ve Büyüköztürk (2017, s. 183) .70 ve üzeri olması gerektiğini; Balcı (2015, s. 113) .80 ve üstünde olması gerektiğini belirtmişlerdir. $\mathrm{Bu}$ bilgilerden hareketle LAP-3 Gelişim Değerlendirme Ölçeği alt testlerinin iç tutarlılığının uygun değerlere sahip olduğu söylenebilir.

LAP-3 Gelişim Değerlendirme Ölçeği'nin güvenirliğine yönelik yapılan çalışmalar kapsamında zaman göre değişmezlik ölçütünü sağlayıp sağlamadığını test etmek amacıyla testtekrar-test güvenirliği $(\mathrm{n}=60)$ için korelasyon katsayıları hesaplanmıştır. Test tekrar test 
güvenirliğine ilişkin korelasyon katsayısı analizi sonucuna göre LAP-3 Gelişim Değerlendirme Ölçeği alt testlerinin üç haftalık arayla yapılan iki uygulaması sonucunda elde edilen puanların birbiriyle pozitif yönde ve yüksek düzeyde anlamlı bir ilişkide olduğu görülmüştür (.93-.99). Ölçeğin orijinalinde ise bu değerler .96-99 arasında değişmekte olduğu (Hardin ve Feisenberg, 2004, s. 36) ve bu araştırmanın sonuçları ile paralellik gösterdiği görülmektedir. Büyüköztürk (2017, s.32) korelasyon katsayısının mutlak değer olarak .70 ile 1.00 arasında olması yüksek, .70 ile .30 arasında olması orta, .30 ile .00 arası ise düşük düzeyde bir ilişki olarak tanımlamaktadır. Bu tanımlamadan hareketle LAP-3 Gelişim Değerlendirme Ölçeği'nin test tekrar test güvenirliğinin kabul edilebilir düzeyde olduğunu söylenebilir.

LAP-3 Gelişim Değerlendirme Ölçeği'nin uygulayıcılar arası uyum güvenirliği ölçütü kapsamında araştırmacı ve okul öncesi eğitim lisans mezunu aynı alanda yüksek lisans yapmakta olan, alanında 10 yıllık deneyime sahip ve daha önce çocuklarla değerlendirme uygulamaları yapmış olan bir hakem tarafindan bir hafta arayla uygulama yapılmıştır. Uygulayıcı 1 ve Uygulayıcı 2 tarafından yapılan uygulamalardan elde edilen sonuçlar arasındaki ilişki Pearson Korelasyon katsayısı hesaplanarak incelenmiştir. Sonuç olarak; kaba motor alt testinde hakemler arası korelasyon katsayıs1 $.88(\mathrm{p}=.000)$, ince motor alt testinde .93 $(\mathrm{p}=.000)$, okuma yazmaya hazırlık alt testinde $.94(\mathrm{p}=.000)$, bilişsel alt testinde $.95(\mathrm{p}=.000)$, dil alt testinde $.91(p=.000)$, özbakım alt testinde $.82(p=.000)$, kişisel/sosyal alt testinde .96 $(p=.000)$, olmak üzere pozitif yönlü yüksek derecede ilişki olduğu görülmektedir $(n=30)$. Ölçeğin orijinalinde yer alan uygulayıcılar arası uyum güvenirliği analiz sonuçları (.84-. 98) da bu sonuçlarla benzerlik göstermektedir (Hardin ve Feisenberg, 2004, s. 37 ). Uygulayıcılar arası uyum güvenirliğine yönelik yapılan analizin sonucunda elde edilen korelasyon katsayılarının pozitif yönlü ve yüksek derecede olan bu ilişki uygulayıcılar arasındaki tutarlığın yüksek olduğunu ifade etmektedir (Johnson ve Christensen, 2014).

Ölçme araçlarının güvenirliğine ilişkin alan yazında yer alan analiz teknikleri uygulanarak güvenirliği test edilen LAP-3 Gelişim Değerlendirme Ölçeği’nin 48-72 aylık Türk çocukları için güvenilir bir ölçme aracı olduğu söylenebilir. 


\section{KAYNAKÇA}

American Educational Research Association (AERA), American Psychological Association (APA), \& National Council on Measurement in Education (NCME). (2014). Standards for educational and psychological testing. Washington, DC:American Educational Research Association.

Bacanlı, H. (2016). Eğitim psikolojisi. (Geliştirilmiş 23. Baskı). Ankara: Pegem Akademi Yayıncilik.

Balcı, A. (2015). Sosyal Bilimlerde Araştırma Yöntem, Teknik ve Illkeler. 11. Baskı Ankara: Pegem Yayıncilık .

Bergen, S. \& Robertson, R. (2013). Healthy children, healthy lives: the wellness guide for early childhood programs. Minnesota: RedLeaf Press.

Bredekamp, S. (2015). Erken çocukluk eğitiminde etkili uygulamalar. (Effective Practices in Early Childhood Education, 2nd Edition). (Çev. Hatice Zeynep İnan ve Taşkın İnan). Ankara: Nobel Yayınc1lık.

Bredekamp, S., \& T. Rosegrant, (ed.). (1995). Reaching potentials: Transforming early childhood curriculum and assessment, Volume 2. Washington, DC: NAEYC.

Büyüköztürk, Ş. (2017). Sosyal bilimler için veri analizi el kitabı istatistik araştırma deseni SPSS uygulamaları ve yorum. 23. Baskı. Ankara: Pegem Yayınc1lık.

Ceylan, F. (2012). Okul öncesi dönem işitme engellilerde müzik eğitimi ile çocukların gelişim özellikleri üzerine terapötik bir çalışma. Yüksek Lisans Tezi. Marmara Üniversitesi Eğitim Bilimleri Enstitüsü. İstanbul.

Coolican, H. (2014). Research methods and statistics in psychology. 6th Edition. USA: Psychology Press.

Fairtest (2007). Criterion and standards referenced tests. http://www.fairtest.org/sites/default/files/criterion\%20fact.pdf. adresinden 9 May1s 2016 tarihinde edinilmiştir.

Hardin, B.J. \& Feinberg, E.S. (2004). The Learning Accomplishmnet profile-3 (LAP-3). NC: Chapel Hill Training Outreach Project, Inc. Kaplan Early Learning Company.

Hills, A.P. \& Byrne, M (2010). An overview of physical growth and maturation. Medicine and Sport Science. Vol 55 (p.1-13). https://www.karger.com/Article//321968 adresinden 20 Nisan 2016 tarihinde edinilmiştir.

Horton, C. \& Bowman, B. T. (2002). Child assessment at the preprimary level: Expert opinion and state trends. Chicago, IL: Erikson Institute for Advanced Study in Child Development. $\quad \mathrm{https}: / / w w w . e r i k s o n . e d u / w p c o n t e n t / u p l o a d s / O P$ hortonbowman1.pdf. adresinden 30 Haziran 2016 tarihinde edinilmiştir.

Johsnon, R.B. \& Christensen, L. (2014). Educational research quantitative, qualitative, and mixed approaches. 5th Edition. USA: Sage.

Karasar, N. (2016). Bilimsel araştırma yöntemleri. 31. Baskl. Ankara: Nobel.

Keenan,T., Evans, S. Evans, \& Crowley,K. (2016). An introduction to child development (3rd Edition). California: SAGE Publication. 
Malina,R.M., Bouchard, C. \& Bar-or,O. (2004). Growth, maturation and physical activity. (2nd Edition). Illinois: Human Kinetics.

Manna, I. (2014). Growth development and maturity in children and adolescent: relation to sports and physical activity. American Journal of Sports Science and Medicine, Vol. 2, No. $\quad 5 A$ 48-50. https://www.researchgate.net/publication/267453319_Growth_Development_and_M aturity_in_Children_and_Adolescent_Relation_to_Sports_and_Physical_Activity. adresinden 18 Mart 2016 tarihinde edinilmiştir.

Mcafee, O. \& Leong, D.J. (2012). Erken çocukluk döneminde gelişimin ve öğrenmenin değerlendirilmesi ve desteklenmesi (Assessing and Guiding Young Children's Development and Learning). (Çev. Ed. Birsen Ekinci). Ankara:Nobel Yayıncılık.

Oktay, A. (2004). Yaşamın Sihirli Yılları. (5. Baskı). İstanbul: Epsilon Yayınevi.

Oktay, A., Bilgin, H. A. (2002). Marmara gelişim ölçeğinin geliştirilmesi (3-6 yaş dönemi çocukları için). Erken Çocukluk Gelişimi ve Eğitimi Sempozyumu Bildiriler Kitabı içinde;s. 64-69, Ankara:.Kök Yayıncılık.

Overton, W. F. ( 2010). Life-span development: concept and issues. In R.M. Lerner, W.F. Overton, A.M. Freund \&M.E. Lamb (Eds), The handbook of life-span development: cognition, biology and methods. (pp. 1-30). New Jersey: John Wiley\&Sons, Inc.

Salkind, N.J. (2002). Child development. NewYork: The Macmillan Psychology Reference Series.

Santrock, J.W. (2013). Life-span development. (13th Edition). NewYork: McGraw Hill.

Senemoğlu, N. (2012). Gelişim, ögrrenme ve ögretim: kuramdan uygulamaya. (21. Baskı) Ankara: Pegem Akademi Yayıncılık.

Shepard, L., Kagan, S.L. \& Wurtz, L. (1998). Principles and recommendations for early childhood assessments. Goal 1 Early Childhood Assessments Resource Group. Washington, DC: National Education Goals Panel. http://govinfo.library.unt.edu/negp/reports/prinrec.pdf. Adresinden 3 Mart 2016 tarihinde edinilmiştir.

Şimşek, H., Yıldırım, A. (2013). Sosyal bilimlerde araştırma yöntemleri. Ankara: Seçkin Yayıncilik.

UNICEF (2003). The state of the world's children 2003. https://www.unicef.org/sowc03/contents/pdf/SOWC03-eng.pdf adresinden 26 Nisan 2016 tarihinde edinilmiştir.

Wise, A. F. (2014). Designing pedagogical interventions to support student use of learning analytics. LAK' 14 Proceedings of the Fourth International Conference on Learning Analytics And Knowledge. p. 203-211. http://dl.acm.org/citation.cfm?id=2567588 adresinden 27 Mart 2016 tarihinde edinilmiştir. 